\title{
What Moves the Highly Skilled and Why? Comparing Turkish Nationals in Canada and Germany
}

\author{
Saime Ozcurumez* and Deniz Yetkin Aker**
}

\begin{abstract}
Based on in-depth interviews with highly skilled and business Turkish nationals (HSBTN) in Canada and Germany, this study aims to explore why HSBTN decide to move and whether migration policy differences among the countries of destination affect recent migration motivations of HSBTN. It mainly focuses on the reasons and rationale of HSBTN and their explanations. This study argues that the high skilled and business migrants in general and HSBTN in particular move internationally as a consequence of individual-level gain beyond economic prospects.
\end{abstract}

\section{INTRODUCTION}

Since the 2000s, states have aimed to encourage the admission of highly skilled and business migrants while preventing the entry of the low-skilled (Castles, 2002: 1146). Highly skilled and business migrants are individuals who have qualifications such as managers, directors, professionals, technicians, students, and are mobile "within the internal labour markets of transnational corporations and international organizations" (Castles, 2000: 270), or seek jobs in international labour markets (Castles, 2000: 270). Countries aiming to attract this group encounter two policy challenges due to gaps in theoretically driven empirical studies on highly skilled migrants' motivations to move. First, while there are several studies focusing on mobility, see Easthope (2009) on identity constructions and mobility; Butcher (2009) on mobility and its possible effects on cultural change and identity, among international migration theories aiming to explain the reasons for international mobility (Massey et al., 1993: 432), very few focus on the reasons behind the decisions of the highly skilled and business migrants to move (Favell, Feldblum and Smith, 2006: 15). Therefore there is a lack of empirical evidence to explain what attracts the highly skilled to a certain country over others. Second, as Castles (2004) emphasizes, "migrants are not just isolated individuals who react to market stimuli and bureaucratic rules" (209). While potentially increased income may be a necessary condition for the highly skilled to select a destination country over others, there is no conclusive research to suggest that this is a sufficient condition. This study aims to fill these gaps in the literature by asking what motivates the highly skilled to move and how they select among potential destination countries.

* Bilkent University, 06800, Ankara

** Namik Kemal University 


\section{REVIEW OF REASONS FOR MOBILITY OF HIGHLY SKILLED}

Meijering and van Hoven (2003) identify three key reasons for the decisions of the highly skilled to move, based on interviews with twenty-two Indian IT professionals in Germany: career, money, and personal experience (176). This research largely confirms the explanations offered by the existing theories of migration. Wang (2013), however, shows that the reasons for Chinese skilled immigrants to move to Hong Kong are complex and diverse. Participants emphasize “'social order', 'rule of law' and 'freedom of speech' as key structural factors, and 'quality of life', 'children's education' alongside 'career prospects' as key personal factors” (Wang, 2013: 389). They consider income level, employment conditions, and "'investment opportunities' available in Hong Kong” as unimportant, contradicting the explanations of existing international migration literature for highly skilled migration (Wang, 2013: 389). A recent study based on data from forty-three semi-structured interviews in Amsterdam, Barcelona, and London (Yanasmayan, 2014) discusses the conflicting findings in the literature. The study confirms Wang's (2013) conclusions and suggests that for highly skilled Turkish migrants in European cities the reasons behind decisions of settlement are "personal" and "quality of life"-related (Yanasmayan, 2014: 37). Moreover, further studies, such as Sunata (2010), who aim generally to discuss social effects on highly skilled migration, focus beyond economic reasons for skilled labour migration. While these studies switch attention toward individual-level reasons for mobility, neither of these findings provides a cross-regional perspective. A cross-regional perspective between Europe and North America is likely to provide evidence on how the highly skilled decide between two markets competing for recruiting talent. Moreover, the literature on patterns of mobility of the highly skilled Turkish nationals suggests that they usually select the US and Canada as primary destination countries (Akcapar and Yurdakul, 2009).

The current study focuses on highly skilled and business Turkish nationals (HSBTN henceforth) in Canada and Germany. By doing so it aims to identify and compare the reasons HSBTN move to these two destinations, which are the most attractive with respect to both structural and individuallevel prospects but have fairly different migration and citizenship policies and histories of migration from Turkey. Since the 2000s, many Turkish university graduates and skilled workers have moved to Canada or Germany. Mostly skilled workers and migrating for economic reasons, this group settled mainly in Toronto, Montreal, and Vancouver in Canada, and Berlin in Germany (Verdugo and Mueller, 2008: 5). The flows to both countries have steadily increased (İçduygu, Göker, Tokuzlu, Paçacı Elitok, 2013: 4).

Immigrants of Turkish origin are fewer in number in Canada (a little over twenty-one thousand) (Ontario, Ministry of Finance, 2014), in contrast to Germany (about three million). The mother tongue of 29,640 immigrants in Canada is Turkish, and slightly over six thousand Turkish immigrants have multiple citizenships (Statistics Canada, 2012). In Germany 26,220 Turkish citizens received German citizenship in 2010 (Federal Statistical Office of Germany, 2013: 24). Turkish immigration flows toward Germany and Canada are very different. In 2010, the number of all the Turkish migration flow to Germany was 26,951 (Federal Statistical Office of Germany, 2013: 28), but in 2006 around 6,350 Turkish immigrants moved to Canada (Statistics Canada. 2009). ${ }^{1}$ Why do these individuals choose Canada or Germany as their destination? This research advances the existing studies on why the highly skilled move in several ways. First, unlike existing research, this study aims to explain why highly skilled people in general and HSBTN in particular migrate by focusing on a particular time period, the 2000s (2000-2010). It focuses directly on individuals' ideas, reasons and rationale, in other words, their manifestation about migration. During the period 2000 2010, Turkey experienced a major economic crisis during which we might expect the highly skilled would be particularly motivated to migrate for economic reasons. Some scholars have cited the economic crisis as resulting in a movement mainly toward the United States (Akcapar, 2009). By studying decisions by HSBTN during this period, this research aims to explain whether reasons 
other than economic gain have factored into the decisions to migrate, and if so, to what extent and why?

In this study, HSBTN in Canada and Germany are selected as two comparable cases. These cases are similar in that all of the individuals moved from big cities in Turkey within the ten-year period of this study's focus as highly skilled and business immigrants. They moved to big cities such as Berlin in Germany and Montreal in Canada. The important difference between these two cases is that HSBTN were exposed to different migration and citizenship policies (Canada with multiculturalist policies versus Germany with restrictive migration and citizenship policies) in their receiving countries.

Both Canada and Germany introduced amendments to their immigration and citizenship policies in the 2000s mainly in response to their labour market and demographic needs. Most of these amendments were geared towards attracting highly skilled and business migrants from around the world. Canada, for example, put into effect the Immigration and Refugee Protection Act (IRPA) in 2001. With this new policy, candidates receive permanent residence according to landing classes that consist of economic class (i.e. skilled workers), family class (i.e. partners and children), and protected persons/refugee class (Elrick, 2007: 2). In Germany, reforms made in the 2000s aimed to facilitate skilled labour migration and provide paths to citizenship acquisition in eight years via legal residence (Süssmuth, 2009: 3). German immigration policy tends to remain restrictive vis-àvis third-country nationals (non-EU citizens) in particular (Süssmuth, 2009: 3). For instance, highly skilled candidates from non-EU countries may receive residence permits for working in Germany only if their services are considered essential, or there is an intergovernmental agreement between Germany and their home countries. After five years, highly skilled immigrants with residence permits (temporary residence permits) may earn the right to have permanent residence (permanent settlement permit) if they fulfill some requirements such as continuing to work in Germany (Federal Ministry of the Interior 2011).

Canada's immigration policy is open to immigrants of all nationalities for entry who qualify for the criteria announced for admission for different categories of candidates. In 2002, Canada introduced the skilled worker selection system currently in place, aiming to select immigrants who can integrate to the labour market in Canada in the longer run (Ferrer and Riddell, 2014:10). However, the challenge of whether new permanent residents may find jobs commensurate with their professional qualifications remains for both countries (Challinor, 2011).

Canada's Multiculturalism Act supports language courses to facilitate integration and allows dual citizenship. In Germany, however, dual citizenship is prohibited except for EU citizens. Changes in Canada's Citizenship Act in 2009, 2011, and 2012 brought slightly more restrictive measures for citizenship acquisition. With the reform in April 2009, for example, parents were not allowed to pass on their citizenship to children born or adopted outside of Canada if the parents were also born in another country (Government of Canada, 2014). Canada continues to experience an increase in naturalization since the 2001 census (Challinor, 2011). In Germany, the 2000 Citizenship Act made naturalization possible (Kaya, 2009: 45). Scholars view this amendment as paving the way to facilitated naturalization by birth for the second and third generations, though the process still not as liberal as Canada's, due to restrictions on dual nationality (Faist, Gerdes and Rieple, 2004: 926-29). On July 3, 2014, a new citizenship law was introduced, which aims to ease some of the restrictive rules, "to allow young Germans of foreign origin to hold two passports - a move that benefits the large Turkish community" (EurActiv, 2014). With the amendment, youth are allowed to have two passports if by the age of 21, "they can prove they have lived in Germany for at least eight years or have gone to school in the country for six years and gained school-leaving qualifications" (EurActiv, 2014). While the new law seems to ease citizenship acquisition for new generations, Turkish community leaders in Germany argue "it remains exclusive for older generations of Turkish origin" (EurActiv, 2014). Whether the HSBTN finalize their destination decisions based on such policies remains unexplored. By focusing on individuals' manifestation about 
migration, this research proposes to focus on the question of whether the perceived benefits of citizenship acquisition of the destination country and entry in a preferred category of migrant (highly skilled and/or business) impact decisions about destination.

\section{RESEARCH DESIGN}

The research is based on data collected via semi-structured, face-to-face, in-depth interviews with sixty-four HSBTN in Canada and forty-eight HSBTN in Germany from March 1-May 31, 2011 and July 1-September 30, 2011, respectively. The characteristics of the sample are as follows: First, the data include only the accounts of those who arrived in the respective countries by their own initiative, not through family reunification. Second, all the participants included in the data moved from Turkey to the destination country directly, and not via other countries, in the period between 2000 and 2010. Third, the interviewees were all highly skilled and business immigrants, though not all were able to establish their businesses or find jobs in Canada or Germany that fit their qualifications. Fourth, the interviewees in both Canada and Germany were identified by the 'snowball' method starting with leads through the associations of immigrants of Turkish origin in both countries and through mailing lists and blogs of immigrants. Although the data were mainly collected in Montreal in Canada and in Berlin in Germany - the main cities that immigrants prefer to move to - several interviews were added from Toronto and Ottawa in Canada, and from Braunschweig and Dresden in Germany. Inclusion of these cities generated comparative data for further discussion about whether there are differences in ideas of highly skilled immigrants living in different cities and/or regions.

The interviewees consisted of 21 males and 27 females in Germany, of whom 44 were in the 20-34 age group and 4 were in the 35-50 age group; and 35 males and 29 females in Canada of whom 21 were in the 20-34 age group, 40 were in the 35-50 age group, and 3 were in the 51-65 and over age group. According to the most recent available data, the number of international students in Germany (where the average in 2004-2009 was 179,000 and in 2010 was 181,200) is almost double those in Canada (where the average in 2004-2009 was 82,600 and in 2010 was 95,600) (OECD 2013: 34). In contrast to the Canada sample (33 of the interviewees in Germany and 4 in Canada were students or researchers), almost half of interviewees in Germany were students (MA, PhD or Post-Doc). ${ }^{2}$ Such a major difference in terms of the occupation of the interviewees may be attributed to the differences in immigration policies between the two countries. In order to attract international students, Germany amended its immigration policies by charging "negligible fees to international students at any enrolment level." (Hawthorne 2008: 14). Such amendments are in line with the goal of developing and implementing policies to attract highly skilled immigrants, among whom international students who arrive for higher education constitute an important group. These students are expected to integrate successfully into the labour market after graduation, and sometimes during their studies. The demographic characteristics of the sample for this study validate the general findings in the literature to this end. The immigration policies' targeting to bring in a specific highly skilled group, in this case international students, seem to have reached its objectives as the comparative evidence of this study's sample demographics shows.

In Germany, 29 of the interviewees were single, 18 were married and 1 was divorced. In Canada, 15 of the interviewees were single, 39 were married, 8 were divorced and 1 was engaged to be married. In terms of occupational groups, 33 of the interviewees in Germany and 4 in Canada were students or researchers; 10 in Canada were IT specialists (none in Germany); 3 were self-employed in each country; 2 in Germany and 7 in Canada were working in jobs outside of their skill set; 10 in Canada worked in the banking sector (none in Germany); 10 in Germany and 17 in Canada held other professional occupations (teachers, architects, legal assistants); none in Germany and 7 in 
Canada and 0 in Germany were unemployed at the time of interview yet actively searching for a job; and 6 in Canada and none in Germany were not working. The demographic data about the occupations of HSBTN shows that although all of the participants were highly skilled and/or business immigrants, not all of the HSBTN were able to or intended to find highly skilled jobs in the receiving countries. This may be related to the challenges of economic integration, a topic for discussion and analysis in further studies. ${ }^{3}$

As for number of children, two in Germany and 27 in Canada had no children; 11 in Germany and 25 in Canada had one child; four in Germany and nine in Canada had two children; one in Germany and three in Canada had three or more children. In Germany, 46 were only Turkish citizens and two were German citizens, and in Canada 27 were Turkish citizens only, 36 were dual citizens (Canadian and Turkish), and one was only a Canadian citizen. When the descriptive characteristics of citizenship status, gender, and accommodation are compared for HSBTN in Canada, most of the Turkish female and male interviewees in the Montreal data are Turkish citizens only. However, it is the opposite in Toronto; the numbers of Turkish migrants who are only Turkish citizens or dual citizens are almost equal. This may be because the number of student interviewees is higher in Montreal than in Toronto. According to the Germany case data, 96.7 per cent of the participants were Turkish citizens only. Only 1.7 per cent were German citizens and 1.7 per cent claimed that they had dual citizenship, a small percentage perhaps because Germany does not allow dual citizenship for most of its Turkish immigrants. The main objective of this study is to identify and explain the potential reasons why the highly-skilled choose to go to one destination country among others by revealing their ideas and preferences while making the decision. Therefore, it does not focus on whether there is a direct link between the ease of citizenship acquisition policies and the decision to move to a country. Nevertheless the interview data suggest that some of the interviewees, particularly those in Canada, made their decisions becauses of Canada's citizenship acquisition policies.

The most recurrent reasons for migrating to Canada were for a better career (14 interviewees), for education (15 interviewees), for living there (19 interviewees), and because of unhappiness about their lives in Turkey (12 interviewees). Another set of repeated reasons to choose Canada as a destination were the high standards of living in Canada (10 interviewees), coming to Canada before to see the country (12 interviewees), having friends and/or having family there (17 interviewees), Canada's migration policy (21 interviewees), for their career development (10 interviewees), and to acquire Canadian citizenship (19 interviewees). Most recurrent reasons to choose Germany as a destination were similar to the ones for Canada: having visited Germany before (12 interviewees), having friends and/or family in the country of destination (21 interviewees), and for career development (34 interviewees). Unlike in Canada, language (13 interviewees) was stated as a reason to choose Germany as a host country. ${ }^{4}$ The top two most common reasons to migrate to Canada and Germany are similar.

The findings suggest that higher wages in the country of destination do not constitute a necessary condition for the HSBTN to prefer one country over another as their destination. HSBTN interviewees state that they migrate to Canada and Germany not for high wages but for better career opportunities and advancement prospects (economic reasons) (14 from Canada and 16 from Germany), and for education (15 from Canada and 38 from Germany).

\section{A COMPARATIVE ANALYSIS}

\section{Social, cultural, and political context}

Earlier comparative studies on highly skilled migration in Europe, North America, and the AsiaPacific stress "the economic impact of highly skilled migration movements has moved beyond mere 
'brain drain' in many contexts, and is now encouraging 'brain circulation' to include new forms of global competition" (Smith and Favell, 2006: 25). This study suggests that one of the most important reasons for HSBTN interviewees to migrate to Canada and Germany is for advanced educational opportunities (15 from Canada and 38 from Germany). However, the answers of HSBTN interviewees from Germany supports OECD results and imply that it is harder for migrants to move to Canada for education only and for highly skilled immigrants other than students to migrate to Germany. Students provide various reasons for preferring to go to Germany, such as scholarship opportunities and geographical proximity. HSBTN find Germany more affordable than other European countries and the United States, citing lower rents and lower (or waived) tuition fees. For these reasons, they prefer Germany as their destination country.

The HSBTN in Canada emphasize affordability of education for the whole family (A33, A39, A52 and A15): "It is a great place to raise a child," one interviewee in Canada said (A15). On the contrary, the HSBTN in Germany highlight the low cost of higher education as well as lower living expenses as a main attraction. The following statement summarizes the emerging pattern for Germany:" I applied to universities in England, Germany, and the Netherlands for PhD. programmes. However, I mostly wanted to come to Germany since England is a very expensive country and there are scholarship options in Germany" (B5). Moreover, most of the interviewees in Germany emphasized that they preferred Germany as their destination country to Canada and the United States precisely for the lower cost of living and education.

\section{Economic reasons: job prospects}

Findings about whether immigrants reflect on career opportunities (i.e. better career prospects than in the country of origin, or any other country of destination) differ between Canada and Germany (14 from Canada and 16 from Germany). The difference is mostly attributable to expectations concerning career prospects in the destination country. While the HSBTN interviewees in Canada state that they moved from Turkey to Canada to find a job and possibly settle, the HSBTN interviewees in Germany are motivated by their desire to qualify for the job market requirements in Turkey by having received education and/or acquired work experience abroad. Interviewees in both countries (such as A51, B2), especially the ones in Germany, highlight that having lived and worked abroad increases their prospects of a higher paying job in Turkey. Interview data suggest that the interviewees in Canada generally moved as a consequence of having a better job opportunity or having qualified as a skilled worker with the high likelihood of finding employment in Canada, and ended up staying (A35, A47, A50). The HSBTN interviewees in Germany, however, mostly state that receiving higher degrees, living and working in Germany increased their opportunities to find high paying jobs in Turkey. An interviewee from Berlin (B9) states, "Since I could not find a job in Turkey, I had to do an MA and a PhD After earning a PhD degree, to find a good job at a university in Turkey, people should have work experience in a foreign country."

Such evidence resonates with the recent findings in exploratory studies on Turkish graduate students in Germany and their decisions on whether "to stay in Germany, to return to Turkey and to move on to another country" (Bilecen-Suoglu, 2014: 76-77). The interview data from Germany suggest that the interviewees are in a transitory period in their lives and aim to make use of their educational and life experience in Germany upon their return to Turkey or their move to another country.

\section{Nature of social policy in destination country}

The HSBTN note that they migrate to Canada to live there (19 interviewees), because they are unhappy about their lives in Turkey (12 interviewees), and because Canada has high living 
standards (as well as social opportunities) (10 interviewees). Such reasoning by the HSBTN in Canada is different from the reasoning of HSBTN in Germany for their respective decisions: For the HSBTN in Canada, the country has a "great welfare state", and is an orderly, "organized and fair," "developed Western country" (A57). They state that such perceptions of Canada affect their choice of Canada as a destination country over other countries (A16). One interviewee expresses his view of Canada as: “...There are great social opportunities. . For instance I have been working here. Therefore, I can satisfy the needs of children (such as affordable and good quality education) and elderly by paying taxes. I know that when I am old, someone will pay for me (cover my costs for elderly care and health care)" (A15). Moreover, the country is seen as supporting single-parent families much better than other countries. For example, one interviewee stresses that such a perception impacted her decision to stay in Canada: "There are many social opportunities for divorced women (in Canada). After I had a divorce, I preferred to stay in Canada" (A30). The HSBTN in Canada repeatedly noted that Canada is a "safe" place to live while interviewees in Germany did not mention any preference for choosing Germany as a destination due to feeling safe in that country.

The HSBTN also decided on the destination country on the basis of prospects for well-being. Interviewees, mostly in Canada but some also in Germany, highlighted how unhappy they were in Turkey as they began to feel, as one interviewee described, like "outsiders in their own country" (A42). By moving to Canada or Germany, the HSBTN aim to reduce their stress levels in the workplace (A42), avoid "metropolitan chaos" (B13) and to lead more peaceful lives "by changing one's place to live" (B28).

\section{SOCIAL NETWORKS AND CHOICE OF DESTINATION}

In keeping with previous findings on how kinship and social networks facilitate the decision to migrate (Faist, 1997; Haug, 2008; Armbruster, 2010), the HSBTN emphasized that having family members or friends as well as a Turkish community and associations in Canada and Germany impacted whether they decided to move (17 interviewees in Canada and 21 interviewees in Germany). HSBTN finalized their decision about which country to move to after family members, friends, or neighbours described life in Germany (B10, B30) or Canada (A12, A4, A16) in very favourable ways, or because they themselves had followed positive comments about life in Germany or Canada on the Internet, in the media or at seminars.

The findings of this study support the idea that having social networks in the country of destination reduces the costs and risks of moving and facilitates further migration to Canada and Germany. These networks support the move by providing information on the destination country, helping in general with the re-settlement by assisting in finding accommodation and introducing newcomers to other Turkish immigrants once they arrive. An interviewee from Berlin stated that she had relatives in Germany and they helped her during migration and settlement (B37), while an interviewee from Toronto explained, "knowing someone in Canada really helps" (A64). The social networks were significant in the first stages of the move and the transitions, though the HSBTN became self-sufficient fairly immediately in both countries. Such findings are similar to results on the behaviour of highly-skilled migrants in London who became self-sufficient in forming their own new social networks (Ryan and Mulholland, 2014).

Related to social ties, the HSBTN in Germany stated language (Turkish language, 13 interviewees) as a reason to choose Germany as a destination country, which was not stated as a reason by Canadian interviewees. Unlike in Canada, there exists a large Turkish population in Germany, and the data show that the presence of such a large population of Turks makes the HSBTN feel confident in moving there even when they do not have a personal connection with anyone already living 
in that country. Various interviewees stated that since many Turkish people live in Germany they decided to move there as well although they had no friends or relatives (B57, B15). An interviewee (B58) stated that living in Berlin was not a challenge at all because he could speak in Turkish when visiting a hospital, pharmacy, grocery, or lawyer. This was because he lived in a neighborhood with a dense Turkish population and preferred to access the services of Turkish doctors or lawyers.

\section{IMMIGRATION AND CITIZENSHIP POLICIES OF DESTINATION COUNTRY}

The findings of this study confirm that immigration and citizenship policies of the country of destination may matter for the HSBTN's choice of destination. Some of the HSBTN in Canada state that they selected Canada over other destinations such as European countries or Australia due to Canada's more liberal citizenship and immigration policies (21 interviewees), or to acquire Canadian citizenship (19 interviewees). This result supports the proposition that migration and citizenship policies of host countries may have an impact on migration decisions of the HSBTN. An interviewee in Ottawa (A22) stated, "I heard that coming to Canada is easier than other countries. So, I decided to come." Another interviewee (A29) had searched immigration policies of several countries and chose Canada as her destination. She stated, "I conducted some research (about immigration policies) of different countries. For instance Australian immigration policy seems unfriendly. I never consider America since its Green Card policy depends mostly on nothing more than luck. I never want to live in Germany. No option left but Canada...". Moreover, the HSBTN characterized the policies in Canada as "immigrant friendly" (A4), and "efficient and clear" (A55). In contrast to the HSBTN in Germany, the HSBTN in Canada were motivated to move to Canada with the objective of pursuing citizenship. An interviewee (A51) explained why the Canadian migration policy is "immigrant-friendly" by noting that after immigrating, people can stay in the country as long as they want to, and Canada allows immigrants to acquire Canadian citizenship within three years.

\section{CONCLUSIONS}

This study examined the reasons behind why the highly skilled and business persons move to some countries and not others, and why they decide to stay in those countries, or not, with a comparative case study of HSBTN in Canada and Germany who moved there between 2000 and 2010. The study fills a significant gap in the literature on why people migrate, why they select one destination country over another by focusing on individual migrants' manifestation about migration. The results show that in the 2000s, the HSBTN mainly decided to migrate because of economic, social, and political reasons and with the help of social networks, as well as expected and lived personal experiences in destination counties.

First, the study maintains that higher wages are neither a necessary nor a sufficient condition for the HSBTN to choose one country over another as their destination. The HSBTN focus on economic opportunities in relation to their career plans. Importantly, HSBTN view their economic prospects in Germany and Canada rather differently. While most of the HSBTN in Canada move to find a job and possibly settle there, the HSBTN in Germany mostly migrate for "foreign" work experience and/or experiences of education "abroad," in order to increase their employment prospects when they return to Turkey. It can be concluded that the HSBTN who prefer to find a job and settle in a county decide to move to Canada, while the ones who wants to have education abroad and find a preferred job in Turkey or in other countries prefer to move to Germany. Thus, 
Germany is seen by the HSBTN as a country to receive an education, whereas Canada is seen as a country to find a job and settle.

Second, the HSBTN also take into account the social, cultural and political context in the country of destination as whole. Prospects for high quality and affordable education for the HSBTN and their families are significant factors influencing their decisions. However, the HSBTN in Canada and Germany differ in how they assess educational prospects. The HSBTN in Canada mostly think in terms of affordable and high quality education for family members, while in Germany the emphasis is on affordable higher education for the HSBTN himself or herself. The HSBTN, mostly those in Canada, emphasize the benefits of a welfare state, such as access to affordable and quality healthcare, childcare, elder care, and unemployment insurance as impacting their decision.

Fourth, the findings of this study confirm that social networks do matter in the choice of destination for the HSBTN. Both in Canada and Germany, having family members or friends in-country; the presence of a large Turkish community; previous visits; and positive comments about destination countries on the Internet impact the decision of the HSBTN to choose one country over another. The findings confirm that social networks reduce economic, social, and psychological costs of moving and transition to settlement in another country. The main difference among those who move to Germany is that the HSBTN in Germany highlight that the presence of a large Turkish community encourages them to move there even if they do not have any social networks themselves. The HSBTN in Canada, however, do not mention the size or characteristics of the Turkish community as impacting their decision to move to Canada. This may be because there is not as large a Turkish community in Canada as the one in Germany.

Lastly, the HSBTNs' mobility accounts for immigration and citizenship policies of the country of destination. If the HSBTN view the destination country as having an "immigrant-friendly" and liberal migration and citizenship policy, then they prefer to move to that country and settle there. The HSBTN in Canada highlight frequently that the Canada's efficient and clear immigration procedure, as well as its policy allowing immigrants to pursue Canadian citizenship within three years, have been the key determinants in their decisions to select one destination country over another.

\section{ACKNOWLEDGEMENTS}

The authors would like to thank two anonymous reviewers for their comments and suggestions on the earlier versions of the article. We are grateful to Mira Vale for proofreading the final manuscript. We would like to also thank The German Academic Exchange Service (DAAD) for providing funds for Deniz Yetkin's stay in Germany between March 1-May 31, 2011), the Scientific and Technological Research Council of Turkey (TUBITAK) for supporting Deniz Yetkin's stay in Canada between July 1-September 30, 2011 for conducting the interviews, and all the interviewees who participated in this study in Canada and in Germany.

\section{NOTES}

1. This research focuses on the period of 2000-2010. The statistical data cited correspond to numbers of immigrants announced by Germany and Canada for this period. Germany and Canada conduct censuses in different years. The study refers to statistics reported in 2006 for Canada - before the more recent 2011 census - to stay within the reported time period.

2. Canada and Germany are selected on the basis of similarities with respect to their offer of opportunities for highly skilled migrants. While similarities are considered, differences are also taken into account. Migration in the ten-year period of study, country of origin, and highly skilled and business status are constant factors across the samples. Participants in Canada held various jobs, and a small number were students; participants 
in Germany also held a variety of jobs, but there were a large number of students. Having students in the study is not a problem for the research question, as the study aims to understand potential reasons for migration. Students are eligible for highly skilled migration or future citizenship applications (although there are different requirements for citizenship in Canada and Germany) and it is seen as convenient to include them in this study.

3. Data from MIPEX on "labour market mobility" indicate that Canada and Germany scored the same (75) for 2007 and 2008 respectively, suggesting a "slightly favourable" environment for "labour market mobility" for migrants. However, in contrast, Canada scored 81 for 2009 and 85 for 2010 for the "labour market mobility" indicator, moving the country to a "highly favourable" score level while Germany remained with the score of 75 in the "slightly favourable category" for the same years. In the period focused in this study (2000-2010), "access to education" scores are available only for 2010 for both countries, with Canada scoring in the "slightly favourable" range and Germany in the "halfway favourable" range. The data available on policies on labour market mobility of immigrants and access to education by immigrants through MIPEX, for example, suggest that more research is necessary on the link between changes in "access to education" policies and "labour market mobility" of immigrants, which is beyond the scope of this study. (See MIPEX Country reports for details, www.mipex.eu/canada and www.mipex.eu/germany, last accessed December 23, 2015).

4. Participants were permitted to state more than one reason to choose Germany or Canada. Reasons repeated more than 10 times are stated here. Some other reasons are discussed as well.

\section{REFERENCES}

Akçapar, Ș.K.

2009 "Turkish Highly Skilled Migration to the United States", in A. Içduygu, and K. Kirisci (Eds), Land of Diverse Migrations, Challenges of Emigration and Immigration in Turkey, Istanbul Bilgi University Press, Istanbul: 109-120.

Akçapar, S..K., and G. Yurdakul

2009 "Introduction: Turkish Identity Formation and Political Mobilization in Western Europe and North America", Turkish Studies, 10(2): 139-147.

Armbruster, $\mathrm{H}$.

2010 "Realising the Self and Developing the African': German Immigrants in Namibia", Journal of Ethnic and Migration Studies, 36(8): 1229-1246.

Bilecen-Süoglu, B.

2014 "Trends in Student Mobility from Turkey to Germany", Perceptions: Journal of International Affairs, 17(2): 61-84.

Butcher, M.

2009 "Ties that Bind: The Strategic Use of Transnational Relationships in Demarcating Identity and Managing Difference", Journal of Ethnic and Migration Studies, 35(8): 1353-1371.

Castles, S.

2000 "International Migration at the Beginning of the Twenty-First Century: Global Trends and Issues", International Social Science Journal, 52(165): 269-281.

2002 "Migration and Community Formation under Conditions of Globalization", International Migration Review, 36(4): 1143-1168.

2004 "Why Migration Policies Fail”, Ethnic and Racial Studies, 27(2): 205-227.

Challinor, A.E.

2011 Canada's Immigration Policy: a Focus on Human Capital, Migration Policy Institute, Available online at: http://www.migrationinformation.org/Profiles/display.cfm?ID=853, (accessed 6 January 2014)

Easthope, $\mathrm{H}$.

2009 "Fixed Identities in a Mobile World? The Relationship Between Mobility, Place and Identity", Identities: Global Studies in Culture and Power, 16(1): 61-82.

Elrick, J.

2007 "Country Profile: Canada", Focus Migration, (8). Available online at: http://focus-migration.hwwi.de/Canada.1275.0.html?\&L=1, (accessed 14 December 2013) 
EurActiv

2014 "Germany Moves to Allow Dual Citizenship", EurActiv, July 4, 2014. http://www.euractiv.com/sections/justice-home-affairs/germany-moves-allow-dual-citizenship-303292, (accessed 21 July 2014).

Faist, T.

1997 “The Crucial Meso Level”, in T. Hammar et al. (Eds), International Migration, Immobility and Development: Multidisciplinary Perspectives, Berg, Oxford: 187-218.

2004 "Dual Citizenship as a Path-Dependent Process", International Migration Review, 38(3): 913-944.

Favell, A., et al.

2006 "The Human Face of Global Mobility: A Research Agenda", Society, 44(2): 15-25.

Federal Statistical Office of Germany

2013 Year Book 2012: Extract of Statistical Yearbook (English version of the chapter as "Population, Families, Living Arrangements"), Available online at: https://www.destatis.de/EN/Publications/Specialized/Population/StatYearbook_Chapter2_5011001129004.pdf?_blob=publicationFile, (accessed 2 January 2014).

Federal Ministry of the Interior

2011 Migration and Integration: Residence Law and Policy on Migration and Integration in Germany. Available online at: http://www.bmi.bund.de/SharedDocs/Downloads/EN/Broschueren/Migration_und_Integration_en.ht\%20ml?nn=2232296, (accessed 2 January 2014), p. 121.

Ferrer, A.M., and W.C. Riddell

2012 "New Directions in Immigration Policy: Canada's Evolving Approach to Immigration Selection", Canadian Labour Market and Skills Researcher Network Working Paper No. 107: 1-36.

Government of Canada

2014 Determine Your Eligibility. Available online at: http://www.cic.gc.ca/english/citizenship/become-eligibility.asp, (accessed 2 January 2014).

Haug, S.

2008 "Migration Networks and Migration Decision-Making", Journal of Ethnic and Migration Studies, 34(4): 585-605.

Hawthorne, L.

2008 The Growing Global Demand for Students as Skilled Migrants, Migration Policy Institute, Available online at: http://www.migrationpolicy.org/research/growing-global-demand-studentsskilledmigrants-0, (accessed 1 May 2014)

Içduygu, A. et al.

2013 "Turkey," in F. Philippe (Ed.), EU Neighborhood Migration Report, European University Institute. Available online at: http://issuu.com/eui-publications/docs/mpc_eu_neighbourhood_migration_repo? mode=embed \&layout=http $\% 3 \mathrm{~A} \% 2 \mathrm{~F} \% 2$ Fskin.issuu.com $\% 2 \mathrm{Fv} \% 2$ Flight $\% 2$ Flayout.xml\&showFlipBtn= true, (accessed 1 January 2014).

Kaya, A.

2009 Islam, Migration and Integration: The Age of Securitization, Palgrave Macmillan, New York.

Massey, D.S., et al.

1993 "Theories of International Migration: A Review and Appraisal", Population and Development Review, 19(3): 431-466.

Meijering, L., and B. van Hoven

2003 "Imagining Difference: The Experiences of 'Transnational' Indian IT Professionals in Germany", Area, 35(2): 174-182.

OECD

2013 International Migration Outlook 2013, OECD Publishing, Ontario, Ministry of Finance. Ethnic Origin and Visible Minorities. Available online at: http://www.fin.gov.on.ca/en/economy/demographics/census/cenhi06-11.html, (accessed 25 January 2014).

Ryan, L.B., and J. Muholland

2014 "French Connections: The Networking Strategies of French Highly Skilled Migrants in London", Global Networks, 14(2): 148-166. 
Smith, P.M., and A. Favell (Eds)

2006 The Human Face of Global Mobility: International Highly Skilled Migration in Europe, North America and the Asia-Pacific (Comparative Urban and Community Research, Vol. 8), Transaction Press, New Brunswick, NJ.

Statistics Canada

2009 Census of Population: Immigrant Population by Place of Birth and Period of Immigration, Available online at: http://www.statcan.gc.ca/tables-tableaux/sum-som/101/cst01/demo24a-eng.html, (accessed 23 January 2014).

20122011 National Household Survey: Data Tables, Available online at: http://www12.statcan.gc.ca/nhsenm/2011/dp-pd/dt-td/Rp-eng.cfm?LANG=E\&APATH=3\&DETAIL=0\&DIM=0\&FL=A\&FREE=0\& $\mathrm{GC}=0 \& \mathrm{GID}=0 \& \mathrm{GK}=0 \& \mathrm{GRP}=1 \& \mathrm{PID}=107551 \& \mathrm{PRID}=0 \& \mathrm{PTYPE}=105277 \& \mathrm{~S}=0 \& \mathrm{SHOWALL}=0 \&-$ $\mathrm{SUB}=0 \&$ Temporal $=2013 \& \mathrm{THEME}=95 \& \mathrm{VID}=0 \& \mathrm{VNAMEE}=\& \mathrm{VNAMEF}, \quad($ accessed 23 January 2014).

Sunata, U.

2010 Highly Skilled Labor Migration: The Case of ITC Specialists from Turkey to Germany, Lit Verlag, Berlin.

Süssmuth, R.

2009 The Future of Migration and Integration Policy in Germany, Migration Policy Institute, Available online at: http://www.migrationpolicy.org/research/future-migration-and-integrationpolicy-germany, (accessed 2 January 2014).

Verdugo, R.R., and C. Mueller

2008 "Education, Social Embeddedness, and the Integration of the Turkish Community in Germany: An Analysis of Homeland Identity", European Education, 40(4): 3-22.

Wang, C.

2013 "Place of Desire: Skilled Migration from Mainland China to Post-Colonial Hong Kong”, Asia Pacific Viewpoint, 54(3): 388-397.

Yanasmayan, Z.

2014 "Further Stay or Return? Insights from the Highly Educated Turkish Migrants in Amsterdam, Barcelona and London", in L. Meier (Ed.), Migrant Professionals in the City: Local Encounters, Identities, and Inequalities, Routledge, New York: 21-39. 